\title{
Identity as a Myth in Pirandello's Works
}

\author{
Ali Jamalinesari \\ Department of English Language and Literature, Islamic Azad University, Ilam Branch, Ilam, Iran \\ E-mail: jamalinesari@yahoo.com
}

Received: 15-02-2014

Accepted: 24-03-2014

Published: 01-07-2014

doi:10.7575/aiac.ijalel.v.3n.4p.150

URL: http://dx.doi.org/10.7575/aiac.ijalel.v.3n.4p.150

\begin{abstract}
The most useful key words to understand Pirandello and at the same time the major recurring ideas and motifs, on which his novelty and greatness depend, include reality, illusion, art and identity. Pirandello seems to have raised several deep questions about identity, truth, the importance of paradox, contradiction and opposition in understanding the truth about the things as well as the significance of point of view and the position of the one who judges in the judgment process which are going to be discussed in this article. Pirandello is polyphonic in so far as to him there is no absolute truth with capital; rather truth is significant only when it is the direct outcome of a particular point of view. Therefore, there are as many truths and identities as there are many points of view.
\end{abstract}

Keywords: Identity, Pirandello, Truth, illusion, Reality, Art

\section{Introduction}

Pirandello was a prolific writer. He produced hundreds of literary works of various genres in his literary life. But his fame and renown rest basically on his essay, On Humor (1974), his Henry IV (1952) and his Six Characters in search of an Author (1979). Since Pirandello was obsessed with a limited number of philosophical dilemmas, he reiterates them over in his works to produce what seems to be a restatement of the same ideas time after time. They permeate all his works, run through all the literary devices, techniques and element he employs, so that even at a fist glance similarity among his works shines much more brilliantly than the differences of genre, situation, incident, etc. Henry IV (1952) and Six Characters in search of an Author (1979), for example, bear so much resemblance to one another that they seem to be two separate efforts to penetrate deep down the nature of the same problems with the same results, the same achievements and the same answers to the same questions. Both examine the paradox of identity. In both of them the humorist is at work with his twofold contradictory stance as the subject and object, the perceiver and the perceived, subject and onlooker. The stance taken with regard to reality, illusion, truth and identity are the same. In both characters wear masks. The main characters in both are vulnerable inside the social roles or masks they put on to survive: his pretense of insanity imprisons Henry for life and the Father in Six Characters in search of an Author (1979) is forced to play a role which reveals only one part of him. The mask limits and struggles to define the character while at the same time it fails to pin down a definite identity. Truth is always concealed in Pirandello, which established his stature as a major dramatist.

What is more interesting and at the same time more terrifying in Pirandello's works, is that, the self conceals itself not only from the others but also from the person himself. A person takes an 'I' as his 'real' identity, then changes it as the time and situation demand to assumes another which is momentarily imposed on the person's perception as the 'real' self and that is how a person can never come to an understanding of his 'true' self, because there is really no true self. It is all a myth. Among the mask a person wears, there are contradictory ones, in sharp contrast to one another. But strange enough to note each determines for the person what is real and true. Each illustrates a truth, leading to a multiplicity of truth, contradictory truth that opposes one another to the highest degree. That is deep revolutionary contemplation frequently occurring in Pirandello: the concept of truth as a paradoxical multiplicity which is going to be discussed further.

\section{Discussion}

In contrast to Aristotle's definition of a play as a complete unified imitation with a beginning, a middle and an end whose frontiers are well defined and whose characters are only characters, Pirandello introduces a kind of play that did not care as much for unification, organic unity or completion as for such major problems as reality and identity. While to Aristotle plot is the major element in a play so that it is possible to have a play without character but not without a plot, Pirandello puts emphasis on character. It is no surprise indeed, since identity, how a person feels his identity, how identity changes, how slippery it is, how difficult it is to pin it down and in what way(s) it is related to a reality which is nothing more than a convenient illusion form Pirandello's major question.

The late nineteenth century drama represented a well- defined world, an indisputable reality, a fixed "I" in each character and by implication in each individual audience and thus, imposed a monologic world view on the spectator or reader. Pirandello, however, revolutionized the stage. Pirandello question not only what a play was aiming at 
achieving before him, but also the nature of the audience, the outlook that served as the common ground between the actor and audience together with all the taken- for- granted beliefs that gave not only art but also the audience a sort of illusive stability. In Pirandello, identity is no fixed notion as it was believed before. Identity is, rather, a slippery mask that an individual wears for a short time as the situation demands and then it is taken out and put a side to give place to another mask is demanded. A major factor on which the nature of a given 'self' depends is the other 'selves' around it, the relationship it assumes to each and the differences that distinguish it from each. Therefore, identity is basically, differential. And since it enjoys no fixed metaphysical content, but changes with the slightest change in the other fluctuating 'selves' its content or significance is delayed forever. It is deferential as well; any discussion of difference has, inevitably, to include the question of time. Each character and by implication each person since Pirandello blurs the boundaries between art and life to give characters 'real' life and identity and to endow the 'real' life of 'real' people a color of artistic illusion - wears various masks and in a continuous shift changes the masks as he or she progresses through time. How can you know a person if not through the mask he wears, in other words through the way he appears to others. This appearance is the only reality there is in Pirandello and the change of appearance is automatically a change of reality. A person has to be accepted by others, so he has to wear a mask that is pleasant and acceptable. The others change of course and the mask has to change overtime. Consequently the coherence and unity of identity is undermined by the changes that time demands, by time itself indeed.

Lack of communication as another persisting theme is a direct outcome of changing appearances. A person, who has a multiplicity of realities and is made to believe in an infinite number of paradoxical truths not only about the others, but about him as well, will not be expected to have a reliable, stable understanding of the others.

Art and its relation to reality is repeated in Pirandello as frequently as the ideas discussed above. Art has a reality or truth of its own. 'Real' life, 'real' situations and 'real' people prove to be nothing more than shadowy illusions compared with the reality of art. They are fleeting, transient, unreliable and slippery. People in 'real' life change their masks, that is, their 'reality' too soon to deserve a fix identity or attribution of a qualification, while art fixes and petrifies life in one moment forever. Characters in a play for instant are fixed in their prison- house of identity forever. They do not change, so they are true embodiments of the characteristics they represent. A father, for example, who nearly committed incest if it was not for an in time arrival of the mother, will regret his intention forever in a play. He cannot escape his fatherhood or his dubious relation to his daughter, or his eternal regret. Apart from his plays, he explores his revolutionary themes in his stories and early novels, in the Outcast (1925) he deals with lack of understanding, the illusory nature of reality and people's suffering from lack of communication.

The hero of one of his best known novels, The Late Mattia Pascal (1923) tries to create himself a fresh identity and leave behind his old one. Pirandello investigates identity on social, philosophical and metaphysical levels. He was well aware of Freudian psychology and especially Freud's discovery of the unconscious fascinated him. It was a cornerstone for him to use as a key to the depth of human ignorance that surrounds the question of identity, reciprocal understanding and the possibility of communication. That human identity is of various levels, that the various parts often clash and oppose one another and the possibility of simultaneous truths, realities and perspectives could be depicted more tangibly with the help of Freud's theories. Fluidity of identity as a major theme runs through the whole works Pirandello created. The protagonist of his novel, One, None, and a Hundred Thousand (1933) is engaged in a process of examining the nature of his identity throughout the work. He notices how unstable, fluid and slippery his identity is. Actually, he notes that his identity depends on the point of view the others adopt. He thought he was one as the little suggests, but he finds that he is a hundred thousand, because it is the viewpoint of the other that determines his identity and the other are a hundred thousand, an infinite number. To be a hundred thousand, one should assume no fixed, stable identity since each of the numerous identities seems illusively as real as the others when it is taken. There is no preference among the identities and therefore, the protagonist is right in feeling that he is none. To be one is a myth, an illusion; he is none since he is a hundred thousand.

The question of reality, illusion and the oxymoron illusive reality as a major theme haunts Pirandello's all genres. In an essay entitled On Humor (1974), he is still investigating his major problems: reality, art, identity and the paradoxical nature of truth. He begins by distinguishing the humorist from the satirist, the ironist and the comic writer. The latter three seem to stick firmly to a binary opposition: I/my opposite, they keep at a safe distance from their opposite, feeling their own superiority and the opposite's inferiority indisputably. The opposite represents what is, which is comic or ridiculous and produces laughter. They themselves stand for what should be, which is normal, serious and worthy of associating with. They are right, the opposite absolutely wrong. But the humorist, feeling the illusive nature of reality and the paradoxical nature of truth lives both the life of himself and that of his opposite. The humorist cannot certainly set a boundary between the opposite and himself. He puts himself in the opposite's shows at the same time that he holds his own position. So at the same time he laughs and feels being laughed at. There is no feeling, no word and no insight in him that does not, automatically and systematically, produces it's opposite. In this case, the humorist is Pirandello's mouthpiece indeed. It is interesting to note that On Humor brought Pirandello the fierce attacks of the Italian philosopher, Benedetti Croce who thought of Pirandello as a pessimistic sophist who created neither art nor philosophy.

Pirandello scrutinizes his major questions in other works as well including his first dramatic success, It Is So [If You Think So] (1952), in Henry IV (1952) as well as Six Characters in Search of an Author (1979). Masquerading as the eleventh- century German emperor, Henry IV, the major character, Henry, falls from his horse and assumes the 
identity of the king. He is confined for twenty years as insane. During these years he is visited by his friends, relative and acquaintances who want to know if he has been cured. Henry proves to have been sober and rational during the last eight years of his long confinement. He has faced his back - breaking dilemma for eight years: Whether he should continue as Henry IV or once be reconciled to a much different identity, as Henry whom he has abandoned for twenty years. To do so requires him to enter a society from which he has been away for twenty years. Finally, when he is sane or rather, in his lucid state, he commits murder and refuses further participation in the chaos of living. Now we shall turn to Pirandello's most anthologized and controversial play.

Undecidability rules and unreadability takes the upper hand in a twentieth century play that narrates a story permeated everywhere with adultery, nudity, prostitution, illegitimacy and potential incest, a story that turns each of these on its head and questions the habitualized way of thinking of them. And that is perhaps, why it caused a riot with people assaulting and jeering at Pirandello when his Six Characters in Search of an Author was first staged in 1921 and perhaps, that is also why it pioneered modern theatre and is of that high a rank in the history of theatre.

Six uncompleted characters interrupt the rehearsal of a play and urge the producer to put aside the play rehearsed and to write instead the play that contains the six characters to complete them as well as their story. Each of the characters tells the same story from his or her point of view and the difference in the point of view leads, inevitably to a difference in the truth as seen by each character. Each is so persuasive and convincing in the narration of the story that the reader (audience) finds no choice better than admitting the relativity or at least multiplicity and multidimensionality of the truth. They challenge the actors, actresses, the director and the audiences by claiming more reality for themselves than the one, the actors, etc. have a claim to. Being a character is one form of existence, they argue, as powerful and self-evident as being an actor or being a human being. A character enjoys a reality no less than a real person. And the existence and reality of a person is subject to question no less than that of a character.

Play merges into reality and reality mingles with play. A character in a play can guide and lead its 'real' author as much as the author can shape the character. They even problematize the concept of identity and oneness of the individual human beings.

Hereafter, it is not difficult to talk about the reality of the characters against the imaginary nature of the existence of the actor, the audience and the reader. Nor is it a painstaking job talk of a character that creates an author, nor of a script that can be found within the characters rather than characters within the script, nor of goodness that turns out to be much worse than wickedness, nor of illegitimate sons or daughters who are at the same time as legitimate as any other son or daughter could be, nor of a daughter who is at the same time her father's mistress or of a father who is his daughter's lover. Binary oppositions in the play are destabilized and the preference of one side over the other is questioned. The binary opposition then is reversed leading the reader (audience) to an aporia from which it is impossible to find the way out.

Six Characters in search of an Author problematizes the conventionally accepted boundary between real and imaginary from the very outset. It opens with a scene representing a number of actors, a producer, a prompter, etc. rehearsing a play by Pirandello, The Rules of the Game. As it will be discussed in more details later, every possible attempt is made by Pirandello to blur the boundary between real and imaginary, between art and life by the lack of any preparation in particular. The actors and actresses enter the theatre from the very entrances that the audience does. To quote the direction from the opening scene of the play:

When the audience enters, the curtain is already up and the stage is just as it would be during the day. There is no set; it is empty in almost total darkness. This is so that from the beginning the audience will have the feeling of being present not at a performance of a properly rehearsed play, but at a performance of a play that happens spontaneously. (1979, p.1)

The actor's rehearsal of the second act of The rules of the game is suddenly interrupted by the arrival of six characters who are seeking the producer. They are out of an unwritten novel who demands to be given dramatic existence. They have been half created and then abandoned by their anonymous writer, and now they ask the producer to act out their play the script of which they claim is in them. The producer, the prompter, the stage hand, the actors and actresses are finally persuaded to give up their own play and instead contribute to the characters' play.

The characters fixed in their roles forever claim to be true and more real than the 'real' people who change mask after mask, that is, 'reality' after 'reality'. Their truth has its origins in the truth of art, fixed, unchanging and stable in contrast to the fluctuating truth of life. Of course, that may be the appearance. On the face of it art seems in Six Characters to be of an unchanging truth, while Pirandello deconstructs himself by introducing shifting points of view that devour the truths of art and life alike. Each character claims and is supposed to enjoy a determined, well- defined identity, but that is an illusion, since each character's identity is determined by the point of view of the others, the characters' included, too. The Father for instance defines his identity, his passion and motivations and has a claim to have uttered the last word on that subject, but from the view point of the daughter he is of a different identity, his passions being other than what he himself suggests and motivations defined quite differently. Still from the Mothers' point of view a third identity displays itself and so on and so forth. 


\section{Conclusion}

No one is one. Everybody is an incongruous combination of different "I"s that change, appear, disappear, dominate, give in, change place and change color through the passage of time, through the changes of place, of opinion, of position, of climate and of a good deal of other factors. The illusory "I" which thinks of itself as real is nothing more than an illusion, a mirage, dismantled and undermined constantly by the foregrounding of an infinite number of other "I"s lurking one behind another and waiting for the slightest opportunity to push aside the one that is temporarily the foremost. Loosening the major anchor that makes possible the imposing of one interpretation of the truth, that is, challenging and undermining the metaphysical belief in the unity and stability of the "I" which is the firmest and the most fundamental cornerstone to prevent the free play of signification and interpretation, is perhaps the main step that can be taken to challenge and problematize any other metaphysical belief that takes an idea for granted.

\section{References}

Bentley, E. (Ed.). (1952). Naked Masks: Five Plays by Pirandello. New York: Dutton.

Pirandello, Luigi. (1979). Six Characters in Search of an Author, Methuen Drama.

Pirandello, Luigi. (1933). One, None, and a Hundred Thousand (S. Putnam, Trans.). New York: Dutton.

Pirandello, Luigi. (1974). On Humor (A. Illiano and D. P. Testa, Trans.). Chapel Hill: University of North Carolina Press.

Pirandello, Luigi. (1923). The Late Mattia Pascal (A. Livingston, Trans.). New York: Dutton.

Pirandello, Luigi. (1925). The Outcast (L. Ongley, Trans.). New York: Dutton. 